\title{
The influence of curing conditions on the chemical distribution in wood modified with thermosetting resins
}

\author{
André Klüppel • Carsten Mai
}

Received: 17 April 2012/Published online: 21 February 2013

(C) The Author(s) 2013. This article is published with open access at Springerlink.com

\begin{abstract}
Scots pine (Pinus sylvestris L.) sapwood was impregnated with aqueous solutions of phenol formaldehyde and methylated melamine formaldehyde resins and subsequently cured in an oven. One set of specimens was cured in plastic bags to avoid drying (wet curing) while another set of samples was heated and water was allowed to freely evaporate (dry curing). Macroscopic resin distribution was investigated using X-ray densitometry and infrared spectroscopy (FTIR-ATR). During dry curing, the resins migrated to the wood surface resulting in a gradient. Wet curing resulted in even distribution of the resins because it was immobilized due to condensation and precipitation in the wood. Neither densitometry nor FTIRATR was found to be generally applicable for investigating resin distribution in modified wood. Wet curing resulted in low cell wall bulking as compared to dry curing, probably because resin precipitated before drying. Storing impregnated wood prior to curing under non-drying conditions ("diffusion phase") also reduced cell wall penetration and bulking.
\end{abstract}

\section{Introduction}

Wood treatment with thermosetting resins, such as phenol formaldehyde (PF) or methylated melamine formaldehyde (MMF), belongs to a group of modifications summarized by Hill (2006) as impregnation modification. Generally, impregnation modification encompasses all methods where the wood substance is filled with the modification agent. Most methods, however, are primarily aimed at filling the cell wall micropores, because most wood properties can only be efficiently changed with the material located in the cell wall rather than in the lumens.

\footnotetext{
A. Klüppel · C. Mai $(\bowtie)$

Wood Biology and Wood Products, Burckhardt Institute, Georg-August-University, Göttingen, Büsgenweg 4, 37077 Göttingen, Germany

e-mail: cmai@gwdg.de
} 
Generally, an impregnation modification is performed with monomer (or oligomers) solutions, which penetrate into the cell wall and undergo subsequent polymerization (mainly polycondensation) to form the resin. Covalent bonds between modification agent and cell wall constituents might exist, though this is not essential for stable fixation. Treatments usually involve impregnation with an aqueous solution of the resin molecules followed by high-temperature drying including resin curing. When wood is impregnated using a vacuum-pressure process, the solution flows into the coarse wood structure driven by pressure gradients. Differences in concentration between the modification solution and the wood moisture are equalized by diffusion. The higher the initial moisture content, the more the diffusion contributes to distributing the solute within the wood (Stamm 1964). Especially cell wall penetration is a primarily diffusion-controlled process, as most cell wall pores are only accessible in a swollen state (Hill et al. 2004). Many researchers, therefore, include a so-called "diffusion phase" into the process. During this phase, the impregnated wood is stored under non-drying conditions, wrapped in foil or kept in the impregnation solution, in order to allow the resin to diffuse into the cell wall (Stamm and Seborg 1942; Schneider 1995; Rapp et al. 1999; Gindl et al. 2003; Furuno et al. 2004).

Both wood drying and resin curing require heat and therefore interact strongly. Usually, they are combined in a single step. In laboratory-scale experiments, impregnated specimens are usually dried and cured in an oven. Starting at low temperatures so as not to induce drying failures, the temperature is gradually increased to ensure complete condensation of the resin (Galperin et al. 1995; Lukowsky et al. 1998; Rapp et al. 1999; Furuno et al. 2004). In commercial processes for the production of resin-treated plywood, veneers are pre-dried after impregnation. Afterwards, they are either cured at higher temperatures in the veneer dryer (Stamm and Seborg 1942) or in a combined step in the hot press simultaneously with curing the glue (Wepner 2006; Dieste et al. 2009; Trinh et al. 2012). Varying a number of manufacturing variables, Millett et al. (1943) found that drastic drying ( $>$ ca. $75^{\circ} \mathrm{C}$ ) severely reduced the impact resistance of PF-treated plywood as compared to mild drying $\left(<\mathrm{ca} .75^{\circ} \mathrm{C}\right)$, while curing conditions had a minor effect.

When wood impregnated with a solution is dried, the outward movement of the solvent results in migration of the solute to the surface. The uneven distribution established during drying can cause inaccuracies at testing the effectiveness against fungi and insects of both conventional preservatives and modifications (Becker 1952; Smith and Cockcroft 1961; Brooks et al. 1973; Klüppel and Mai 2011). Most resin treatments, however, do not only improve durability but also affect the dry volume of the wood (bulking), dimensional stability and sorption behaviour as well as strength and elastic properties (Hill 2006). Concentration gradients reportedly cause strains inside the wood, which can lead to checks and deformation (Ashaari et al. 1990). Krause (2006), for example, reported on bone-shaped boards due to longitudinal migration of the resin from the board centre to the end face. Gradients also formed in wood treated with furfuryl alcohol (Schneider 1995) and MMF resin (Rapp 1999), respectively, but were ascribed to incomplete impregnation. 
In the textile industry, not only dry curing but also wet curing processes are used to cure fabrics treated with the thermosetting resin DMDHEU (dimethyloldihydroxy-ethylene-urea). For wet curing, the resin is cured in wet state under nondrying conditions followed by drying. Nicholas and Williams (1987) and Krause (2006) transferred this process to DMDHEU-treated wood and achieved a macroscopically uniform distribution, because the resin is immobilized before drying starts. Krause (2006), however, also found a smaller increase in dimensional stability, hardness and durability as compared to dry curing. Curing of urea-resin treated wood at $70{ }^{\circ} \mathrm{C}$ and $75 \% \mathrm{RH}$ resulted in considerable lower anti-shrink efficiency (ASE; percentage decrease in maximum swelling) than curing at $70{ }^{\circ} \mathrm{C}$ and $2 \%$ RH (Millett and Stamm 1946). The authors assumed that resin molecules diffused from the cell wall into the lumens under humid conditions.

While it should be generally possible to transfer a wet curing process to industrial scale, this is unfeasible for pure dry curing. Drying commercially sized timber under absolute dry conditions would lead to steep moisture gradients inside the wood and, thus, cause drying failures like checks, cracks and warp. To efficiently dry timber in a kiln, the wood is usually heated up under moist conditions, so that water movement inside the wood is accelerated while evaporation from the surface is limited. Consequently, resin treatments utilizing kiln drying necessarily involve, at least, a short wet curing phase.

Only few studies on the upscaling of resin treatments are published. Millett and Stamm (1954) transferred the process for the production of PF-treated plywood to solid wood. Using a kiln for drying and a hot press for curing, they found that the treatment of the solid wood specimens showed appreciably less improvement in hardness and moisture resistance than that of panels made from individually treated veneers.

In most studies, macroscopic distribution of wood preservatives and modification agents was assessed by taking subsamples from different parts of a specimen followed by determining either the chemical content of the subsamples or related properties like swelling behaviour (Nicholas and Williams 1987; Ashaari et al. 1990). This is a relatively laborious and time-consuming method where the spatial resolution is confined to the size of the subsamples. Jensen et al. (1992) monitored the penetration of resins into wood by means of infrared spectra on thin slices cut perpendicular to the direction of penetration using the ATR-technique (attenuated total reflection). Additional sample preparation was not required, and resolution was increased to the thickness of the slices. However, the method still involved the preparation of subsamples. Without this step, ATR-FTIR would be a convenient method to rapidly assess resin distribution in modified wood. As impregnation modification adds a considerable amount of material to the wood, densitometry should provide another simple method to record chemical distribution in modified wood with relatively high resolution (Rapp 1999; Olsson et al. 2001). In wood science, it is routinely used for measuring the vertical density profile of wood-based panels (Wang and Dai 2004) or the year-ring structure of solid wood (Polge 1978) and it is, therefore, readily available at many research sites.

It is assumed that curing conditions crucially affect not only macroscopic chemical distribution but also intrinsic properties of resin-treated wood. Besides 
total resin content, cell wall penetration is the main factor affecting these properties. In this study, the effects of curing conditions on resin distribution and cell wall penetration of wood treated with MMF and PF were investigated. Macroscopic resin distribution was investigated by means of densitometry and ATR-FTIR. These methods were supposed to offer a faster and more convenient alternative to procedures that involve the cutting of subsamples.

\section{Experimental}

\section{Treatments}

For all experiments, Scots pine (Pinus sylvestris L.) sapwood was treated with a low molecular weight resol $\left(M_{n}=\right.$ ca. $\left.400 \mathrm{~g} / \mathrm{mol}\right)$ with sodium hydroxide $(\mathrm{NaOH})$ as a catalyst or a low molecular weight methylated melamine formaldehyde resin ( $\mathrm{pH}=9.6)$. Unless otherwise stated, conditioned $\left(20^{\circ} \mathrm{C}, 65 \% \mathrm{RH}\right)$ specimens were treated in a vacuum-pressure process $(0.5 \mathrm{~h}, 100$ mbar followed by $2 \mathrm{~h}, 12$ bar $)$ with aqueous solutions exhibiting a solid content of $30 \%(\mathrm{~m} / \mathrm{m})$. After impregnation, all specimens were exposed to the same temperature cycle: $20,40,75,40$ and $103{ }^{\circ} \mathrm{C}$. The duration of each step was $24 \mathrm{~h}$. For wet curing, the specimens were packed in polyethylene terephthalate (PET) bags during the first three steps.

\section{Densitometry}

A board with a cross section of $20 \times 50 \mathrm{~mm}^{2}(r \times t)$ was cut into sections of $20 \mathrm{~mm}$ length, and the end faces of the specimens were sealed with tape to avoid axial flow. In this way, impregnation and drying conditions in the middle of a board were simulated. A densitometer for measuring the density distribution of woodbased panels was used to record the density profiles of the oven-dry blocks (DAX, Grecon, Alfeld, Germany) before and after modification. The specimens were inserted in such a way that the X-ray ran longitudinally through the sample and the profile displayed the density distribution in radial direction, that is, the thickness of the board (Fig. 1). Density was recorded at a resolution of $0.02 \mathrm{~mm}$.

\section{Infrared spectroscopy}

Fourier transform infrared (FTIR) spectra of conditioned $\left(20{ }^{\circ} \mathrm{C}, 65 \% \mathrm{RH}\right)$ specimens were recorded by means of the attenuated total reflection (ATR) technique (DuraSamplIRII, SensIR Technologies, Warrington, UK), using a Vektor 22 spectrophotometer (Bruker, Bremen, Germany) (64 scans, $4 \mathrm{~cm}^{-1}$ resolution). Background spectra were collected with the empty ATR unit. The baseline correction was made using the rubber band method in the OPUS software (64 points, Bruker, Bremen, Germany). All spectra were Min-Max normalized in the region $1800 \ldots 800 \mathrm{~cm}^{-1}$, with the highest peak (at approximately $1,030 \mathrm{~cm}^{-1}$ ) being set to an absorption of $2 \mathrm{AU}$. Two spectra of the centre and the edge region, respectively, were recorded on the cross section of each of the five specimens 


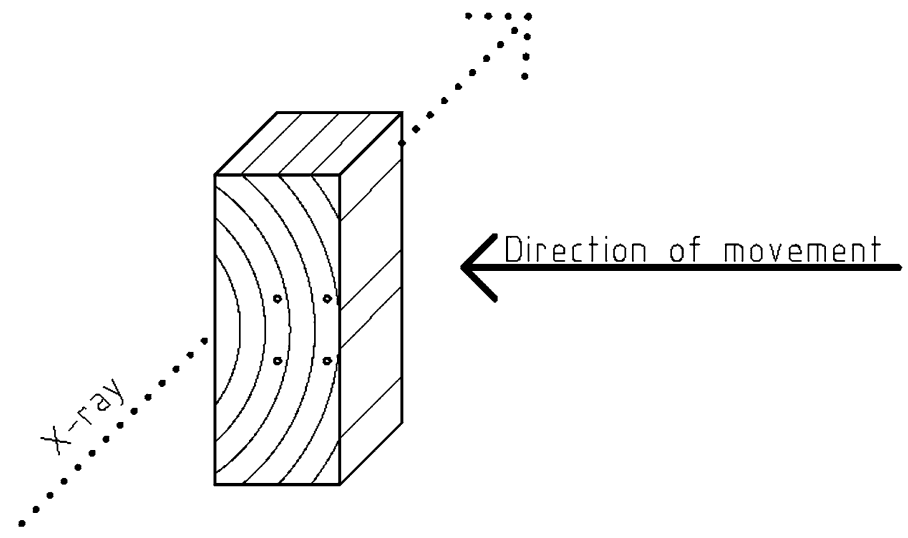

Fig. 1 Positioning of specimens for the density profile measurement; circles show locations for FTIR measurements

(Fig. 1), resulting in ten spectra per treatment and region. Absorption at 1,275 and $813 \mathrm{~cm}^{-1}$ was used to relatively quantify the PF and MMF content, respectively, on the cross sections.

Cell wall bulking, weight percent gain and total swelling

Blocks measuring $25 \times 25 \times 10 \mathrm{~mm}^{3}(r \times t \times l)$ were treated together with the specimens for the density profile determination in order to assess the effect on dimensional stabilization. To investigate the swelling behaviour, the modified specimens were vacuum-impregnated with water, kept submerged for $24 \mathrm{~h}$ and mass and dimension of the water-saturated specimens were recorded (Cycle 1). Then, the specimens were carefully oven-dried, and mass and dimensions were determined again. Finally, the respective data were recorded after vacuum impregnation followed by storing for 2 weeks under water (Cycle 2). Mass and cross-sectional dimensions were determined before and after modification as well as after each soaking and drying step. The longitudinal length was not taken into account. Weight percent gain (WPG) was calculated as percentage change in ovendry mass due to modification based on mass of the untreated specimen. Crosssectional bulking (B) and total swelling ( $S^{\prime}$ ) were defined according to Ohmae et al. (2002):

$$
B=\frac{A_{\mathrm{td}}-A_{\mathrm{ud}}}{A_{\mathrm{ud}}} \times 100[\%]
$$

where $A_{\mathrm{td}}$ is the area of the treated specimen in dry condition; $A_{\mathrm{ud}}$ is the area of the untreated specimen in dry condition.

$$
S^{\prime}=\frac{A_{\mathrm{tw}}-A_{\mathrm{ud}}}{A_{u d}} \times 100[\%]
$$

where $A_{\mathrm{tw}}$ is the area of the treated specimen in water-saturated condition. 
Data in dry state were recorded at the beginning of each cycle, so that WPG in the second cycle was calculated based on the specimens' mass prior to the second soaking phase. Five replicates were used for both density profile and swelling measurements.

\section{Diffusion phase}

Specimens measuring $25 \times 25 \times 10 \mathrm{~mm}^{3}(r \times t \times l)$ were impregnated with PFresin (1 h, 100 mbar), to assess the effect of a diffusion phase between impregnation and curing. One group of specimens (10 replicates) was oven-dried before impregnation, while the other one was stored over water in a desiccator at ca. $100 \%$ $\mathrm{RH}$ for a week. After impregnation, one half of each group (5 replicates) was immediately dried at 20,40 and $103{ }^{\circ} \mathrm{C}$ for $24 \mathrm{~h}$ each. The other half was stored in polyethylene (PE) bags for $48 \mathrm{~h}$ before it was subjected to the same drying procedure. Mass and dimensions were recorded after each phase.

\section{Results and discussion}

\section{Densitometry and FTIR}

Macroscopic (radial) resin distribution was investigated by means of densitometry and ATR-FTIR. All density profiles of each treatment displayed similar patterns (Fig. 2): treated specimens throughout exhibited higher density, with no radial gradient in wet-cured specimens. After dry curing, however, there were narrow but distinct peaks on the surface of specimens impregnated with MMF resin but there was no radial slope in PF-treated wood. Infrared spectra of $\mathrm{PF}$ and $\mathrm{MMF}$ resins exhibit distinctive absorption at $1,475 \mathrm{~cm}^{-1}$ (aromatic $\mathrm{C}=\mathrm{C}$ of phenol, Poljansek and Krajnc 2005) and $813 \mathrm{~cm}^{-1}$ (triazine ring of melamine, Gindl et al. 2004), respectively (Fig. 3). Absorbance at these wavenumbers was used to quantify the resin content. Based on these measurements, significant differences between the specimens' centre and edge region (Wilcoxon test: $p<0.05$ ) were found only for PF-modified boards after dry curing (Fig. 4). The cross sections of the PF-treated samples showed large radial cracks (dry curing) or slight cell collapse (wet curing) while there were no cracks in the MMF-treated wood irrespective of the curing (Fig. 5).

Both methods employed here indicate that there was no radial gradient in resin content after wet curing, but on dry-cured specimens, the FTIR and densitometry gave contradictory results revealing the shortcomings of both methods: although density profiles showed that the MMF resin accumulated within a narrow surface layer of about one millimetre in thickness, there was no difference in the respective FTIR absorption. The spatial resolution of the FTIR measurements is limited by the size of the ATR crystal (ca. $1 \mathrm{~mm}$ ) - the penetration depth of the IR radiation of approximately $1 \mu \mathrm{m}$-and because the specimen is only manually positioned on the crystal. The authors, therefore, suggest that the resolution of this measurement was insufficient to detect the narrow peak. In PF-treated and dry-cured specimens, FTIR 


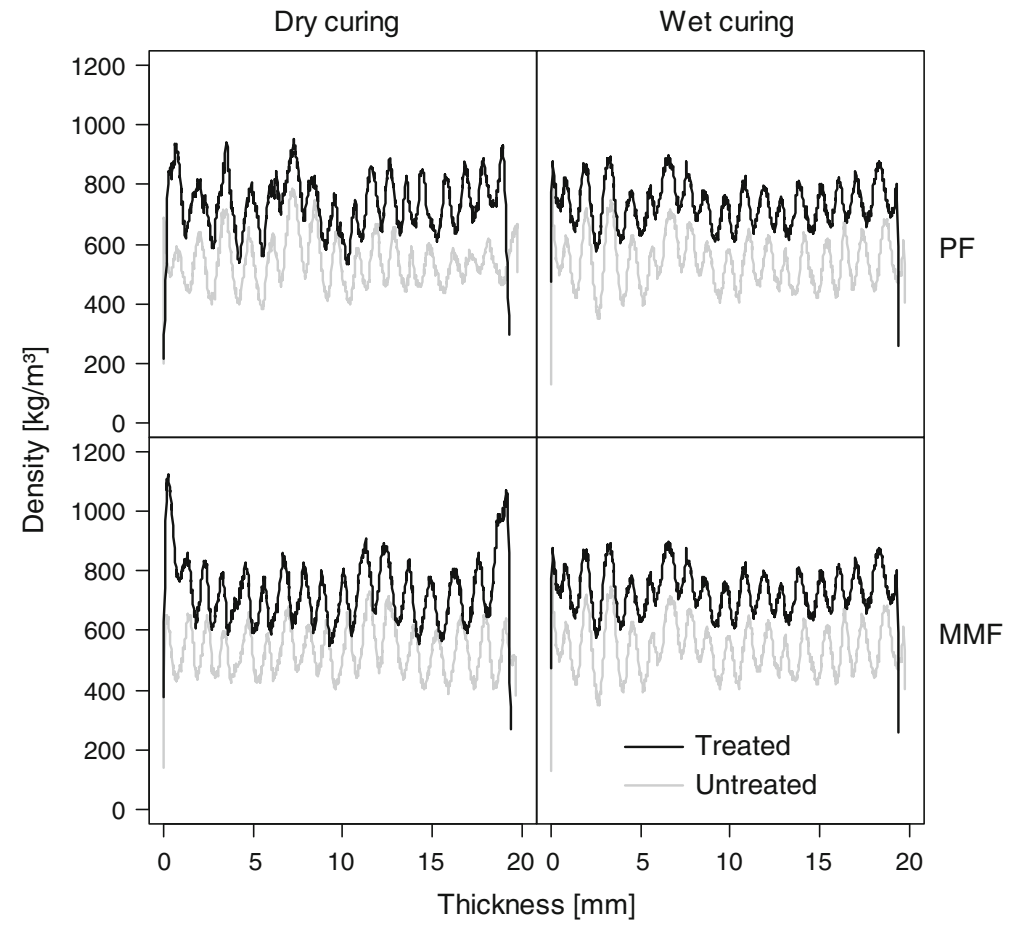

Fig. 2 Density profiles of wood samples before and after resin treatments; $P F$ phenol formaldehyde, $M M F$ methylated melamine formaldehyde

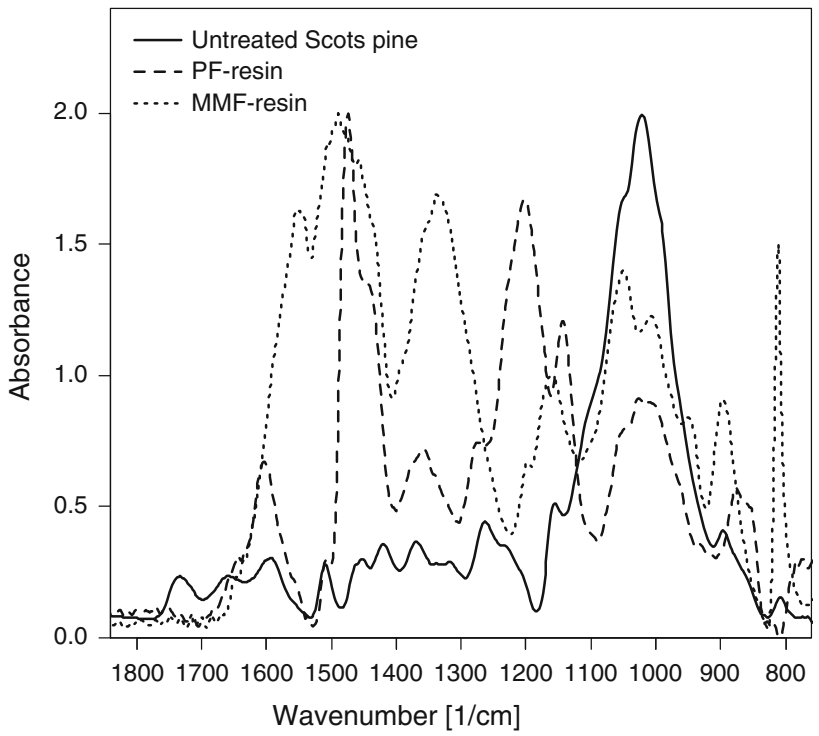

Fig. 3 ATR-FTIR spectra of the resins used and untreated wood (Min-Max normalized in the region shown) 


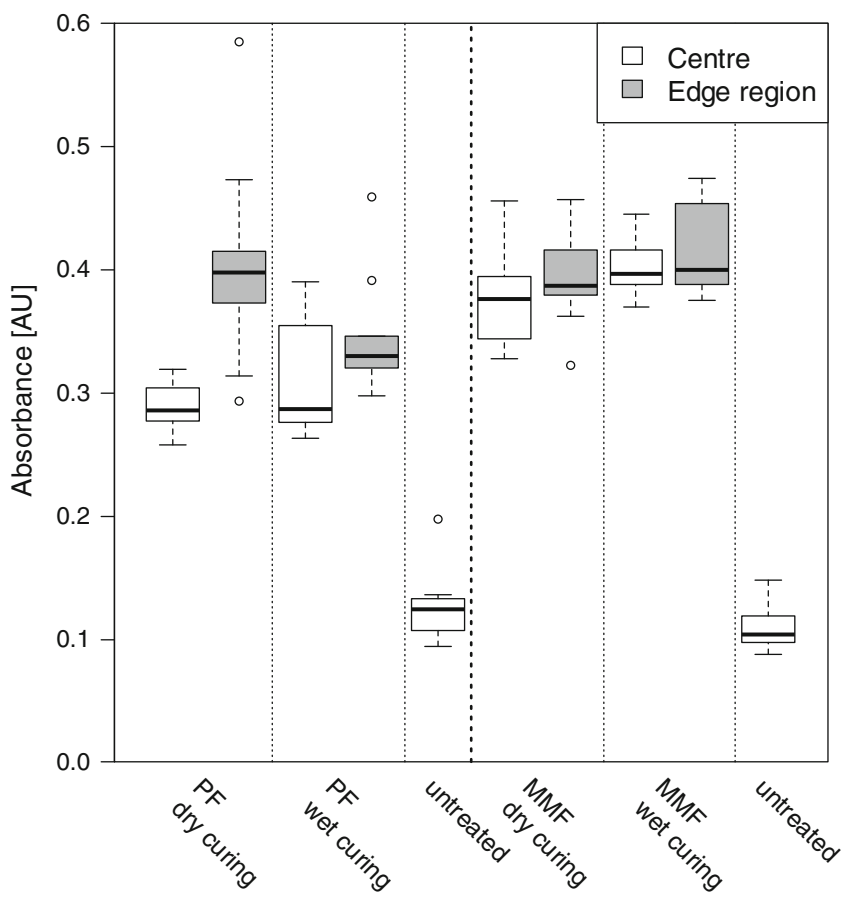

Fig. 4 Infrared absorbance of resin-treated wood at $1,475 \mathrm{~cm}^{-1}$ (left side) and $813 \mathrm{~cm}^{-1}$ (right side) recorded in the specimen's centre and edge regions

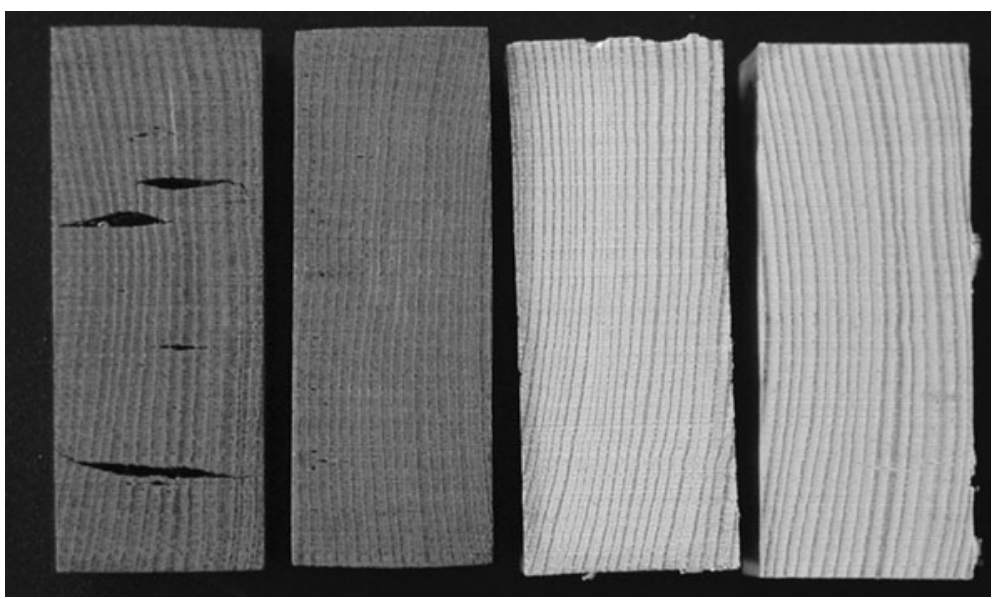

Fig. 5 Cross sections of wood specimens after resin treatments. From left to right: PF (dry curing), PF (wet curing), MMF (dry curing), MMF (wet curing)

measurements, conversely, suggest higher resin concentration in the edge region as compared to the centre, while density profiles do not display any gradient. This difference might be attributed to the fact that the resin does not only increase mass 
but also the dry volume of the wood, because resin deposited in the cell wall causes bulking (see below). As a consequence, volume due to bulking partly compensates for the increase in mass resulting in lower density changes. Because of the radial gradient, bulking was higher near the surface than in the centre. As a consequence, tensile stresses evolved in the core might have caused the cracks shown in Fig. 5. In summary, wet curing seemed to immobilize the resin, so that migration did not occur during drying, while dry curing resulted in an uneven resin distribution of both resins. Neither densitometry nor FTIR-ATR measurements, however, detected the gradients of both resins.

\section{Cell wall bulking}

PF-treatment resulted in a higher WPG (ca. $50 \%$ ) than MMF-treatment (ca. $40 \%$ ). In spite of similar concentrations of the impregnation solution, the WPG of MMFtreated specimens was lower, because methanol is split off and evaporates when MMF polycondenses. Leaching during the first soaking phase reduced mass and bulking (Fig. 6). These changes were only small for most treatments, but noticeably higher in dry-cured MMF-treated wood. After dry curing, PF caused higher bulking than MMF, with tangential bulking being higher than radial bulking. As compared to dry curing, wet curing resulted in considerably lower tangential bulking and even negative radial bulking. Total swelling in water was reduced by the wet-cured PFtreatment, while it was slightly increased by the other treatments.

Generally, modification can affect the dry dimensions of wood in two ways: when the cell wall is filled with the modification agent, it is kept in a swollen state under dry conditions so that dry dimensions increase (bulking). Degradation and leaching of cell wall polymers, on the other hand, result in "negative bulking" (Ohmae et al. 2002). The actual bulking caused by a resin treatment can be assumed to be a combination of both effects. In the present study, type of resin, anatomical direction and curing conditions affected bulking. PF probably caused higher bulking as compared to the MMF due to, smaller molecule size, a wider molecular size distribution and a higher WPG. As the resin is deposited in pores made accessible through swelling in water, it is obvious that bulking correlates with maximum water swelling and, thus, tangential bulking exceeds radial bulking. The effect of curing conditions can be explained as follows.

After impregnation, all lumens and micropores are assumed to be filled with the impregnation solution (see below). Because the ionization of the cell wall polymers is relatively low, the Donnan effect is negligible and the concentration of the modification chemicals in the bound water (cell wall) and free water (lumens) is virtually uniform (Stamm 1934). During drying, free water from the lumens evaporates first, so that the chemical concentration in the lumens increases. The concentration gradient between lumen and cell wall, then, results in diffusion of dissolved molecules into the cell wall micropores. If polycondensation is not taken into account, this process continues until the solution is saturated and the resin precipitates (Stamm 1964). Consequently, the amount of chemical deposited in the cell wall strongly depends on its solubility. 

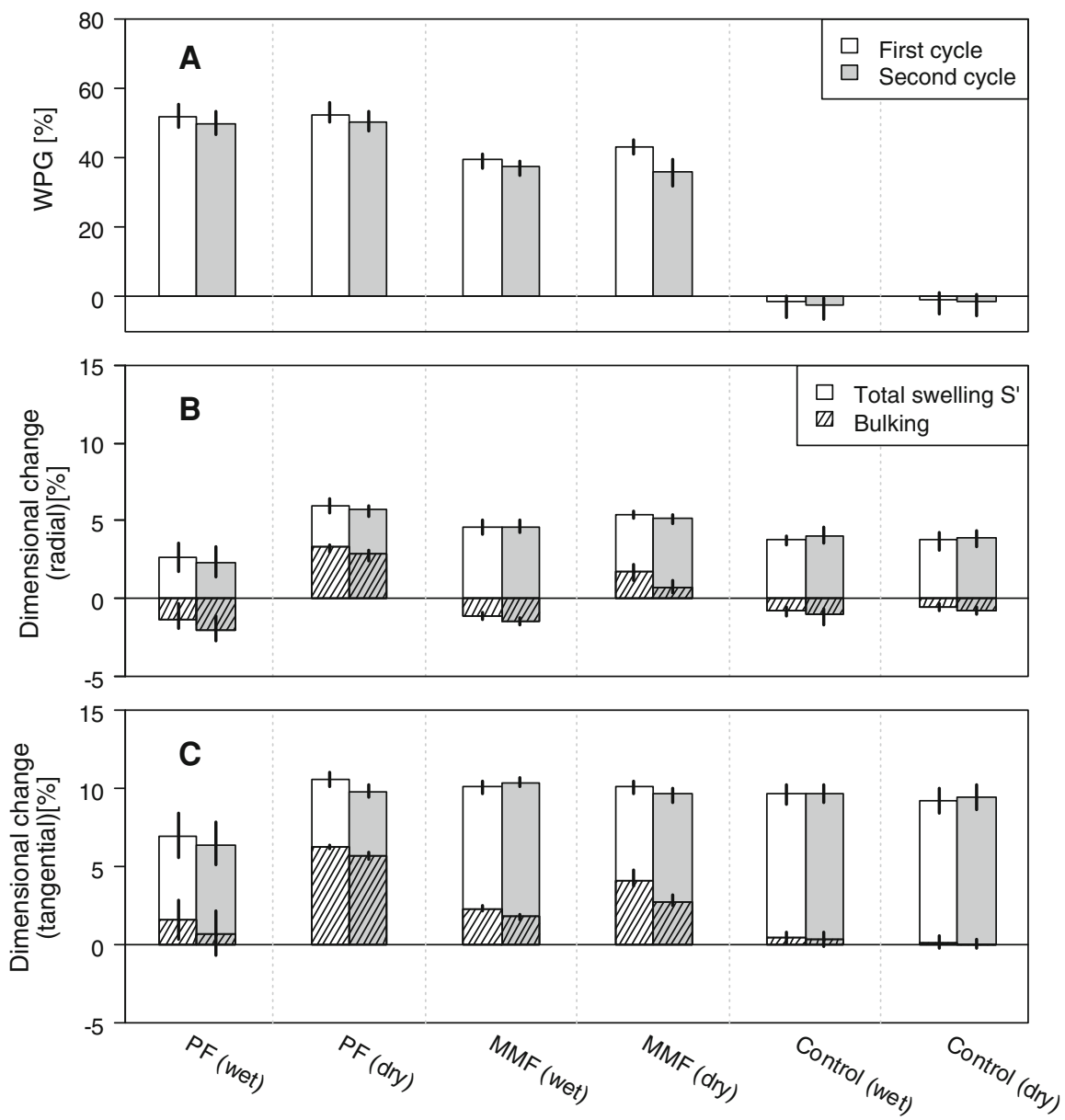

Fig. 6 WPG (a), radial (b) and tangential (c) changes and cell wall bulking of specimens during two drying-soaking cycles: first cycle: dry specimens (after modification; bulking, WPG) were vacuumimpregnated with water and soaked for $24 \mathrm{~h}$ (S'). Second cycle: specimens were carefully dried (bulking, WPG), water impregnated and soaked for 2 weeks (S'). Bars: mean values; error bars: total range (minimum to maximum)

During wet curing, the resin molecules undergo polycondensation while they are solubilized. As molecular size increases, solubility decreases, so that the resin finally precipitates and, therefore, does not migrate during subsequent drying. For the same reason, diffusion into the cell wall is confined to the initial impregnation process. It is suggested that this is the main reason for the low bulking attained with wet curing. Additionally, negative bulking and reduced total swelling (PF) is indicative for the degradation of cell wall polymers (Seborg et al. 1953; Kamdem et al. 2002). It seems to be likely that degradation is more severe under wet curing conditions, because the degree of hydrolysis is higher (particularly because of the high $\mathrm{pH}$ of the impregnation solution). 


\section{Diffusion phase}

In an additional experiment, the effect of a diffusion phase between impregnation and dry curing was investigated on oven-dry and fibre-saturated wood (Fig. 7). Some of the specimens stored over water showed moisture contents up to $65 \%$, which was probably caused by condensed water at the lid of the desiccators that dripped onto the wood. During impregnation, the conditioned specimens swelled slightly, and the dimensions of oven-dried samples increased to the same degree of swelling. Within the first $24 \mathrm{~h}$ after impregnation, the dimensions of all specimens slightly increased further, although without diffusion phase the moisture content of specimens decreased to about $30 \%$ (based on mass of treated wood). WPG was lower (Fig. 8) in previously fibre-saturated specimens resulting in higher moisture contents (based on mass of treated wood) and lower bulking (Fig. 7). Taking into account the WPG, a diffusion phase decreased bulking (Fig. 8).
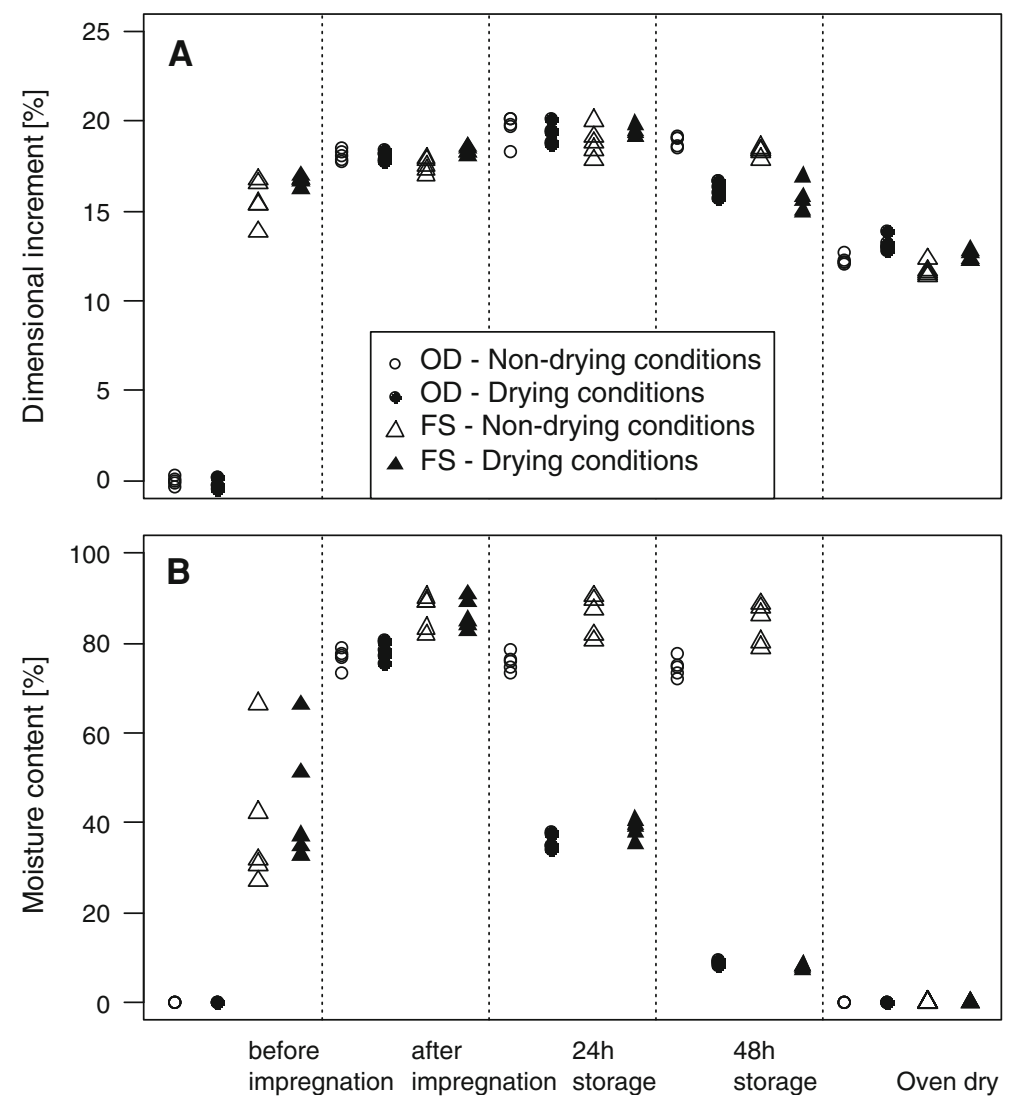

Fig. 7 Dimensional increment (a) and moisture content (b) of PF-treated specimens stored under drying and non-drying conditions after impregnation. The dimensional increment and moisture before impregnation are based on untreated, oven-dry conditions. Moisture after impregnation is based on treated, oven-dry mass. OD/FS: oven-dried and fibre-saturated before treatment 


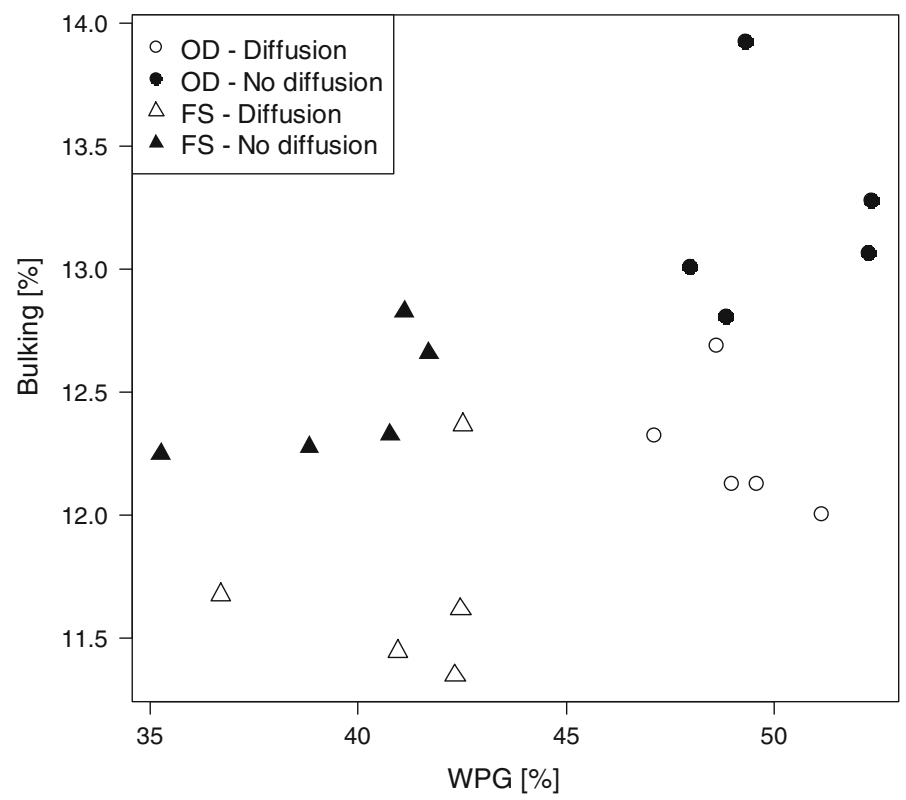

Fig. 8 Effect of a diffusion phase and moisture content prior to treatment on cross-sectional bulking and WPG of PF-treated specimens

When pine sapwood is impregnated using a full cell process, all voids available are filled with the impregnation solution. In wood above fibre saturation point (FSP), the solute then diffuses into the water already present in the wood. At moisture contents below FSP, the cell wall additionally swells when the solution enters the cell wall (which can also be considered a diffusion process). To allow for cell wall penetration, it has been frequently suggested to store the impregnated specimens under non-drying condition or in the impregnation solution before drying. The recommended duration ranged from a day to some weeks (Hill 2006). A diffusion phase would increase cell wall penetration, if at least one of the underlying processes, that is, swelling and diffusion, requires more time than already available during or after impregnation and instead takes place under the conditions prevailing during additional storing.

In this experiment, most of the swelling occurred during the impregnation time of $1 \mathrm{~h}$. As a consequence, oven-dried wood prior to treatment exhibited higher bulking than fibre-saturated wood: by occupying voids, the bound water obviously reduced solution uptake by the cell wall, while in the oven-dried wood, the respective voids were made accessible through swelling by the chemical solution. Irrespective of being dried, swelling continued during the first $24 \mathrm{~h}$ after impregnation but not afterwards. This is in accordance with Mantanis et al. (1994), who found that the rate of swelling, following first-order kinetic, is extremely high in the beginning and decreases exponentially.

Storing the impregnated wood under non-drying conditions before drying, that is, wrapped in polyethylene sheet or a similar material in order to maintain high 
moisture content, resulted in less resin diffusing into the cell wall and, thus, lowered bulking. This finding confirms the assumption that a crucial part of the resin enters the cell wall only during drying. Accordingly, considerable amount of resin did not enter the cell wall during the diffusion phase. In fact, the resin seemed to condense in the lumens so that either molecules became too big to enter the cell wall pores or solubility of the resin decreased, reducing the (saturation) concentration and leading to precipitation of the resin during drying. This means that the "diffusion phase" has an effect comparable to a mild wet curing.

The experimental setup of studies revealing higher resin contents in the cell wall after a diffusion phase, usually differed from the one used in this study in one of two respects. If wood is treated by mere soaking rather than a vacuumpressure process or if the moisture content before impregnation is far above fibre saturation point, the wood is only partly and inhomogeneously filled with the impregnation solution. In this case, the resin would not primarily diffuse from the lumens into the cell wall, but from treated to non-treated areas on a macroscopic scale. Due to the longer distances, this takes more time than cell wall penetration; in the poorly treated areas, it increases the final chemical concentration. Accordingly, Seborg et al. (1962) stated that diffusion time before drying will depend upon how uniformly the resin is distributed during the treating process. A second detail that may influence the effect of a diffusion phase is whether the wood is stored outside the impregnation solution or kept submerged. Treating large dimensions, only the former method is conceivable and has been described above. In laboratory-scale experiments, however, specimens are sometimes soaked for days or weeks. Then, resins like PF and MMF condense faster inside the wood (and especially in the cell wall) than in the surrounding solution, because the acidic wood constituents catalyse polycondensation. As a consequence, the osmotic potential in the wood decreases and low molecular compounds continue to diffuse into the specimen during the diffusion phase and, thus, increase cell wall penetration (Lukowsky and Peek 1998).

Wood modification with thermosetting resins usually aims at both even distribution and maximum cell wall penetration. The results of this study suggest that these objectives are conflicting. If the resin is immobilized before drying to avoid migration, it is concomitantly prevented from diffusing into the cell wall. The larger the dimensions of wood, the more crucial this contradiction. Therefore, it states a particular problem in upscaling modification processes. When kiln drying is required (e.g. for curing), the drying schedule is restricted by the demand to avoid drying failures. Achievable cell wall penetration in commercially sized timber is necessarily lower because it has to be dried more carefully than laboratory-scale specimens. This seems to be a crucial factor for the relatively poor performance of wood treated in large dimensions. One way to enhance diffusion into the cell wall might be vacuum drying. Under vacuum, the resin condenses more slowly because a lower drying temperature is required. This method is employed, for example, in the commercial process of furfurylating timber, at which impregnated wood is vacuumdried prior to steam curing and kiln drying (Hill 2006; Lande 2008). 


\section{Conclusion}

ATR-FTIR spectroscopy and densitometry can be principally used to determine resin distribution in modified wood without the laborious procedure of cutting subsamples. Both methods, however, show important drawbacks: density is an imprecise indicator for the chemical content because density changes due to modification with cell wall-penetrating resins are affected by an increase in both mass (WPG) and volume (bulking). In fact, different WPGs can result in a very similar density. If ATR-FTIR measurements are conducted directly on the cross section of the wood samples, that is, without cutting slices, resolution is limited to a few millimetres and quantitative measurements require laborious calibration (e.g. partial least squares regression; PLS) (Stefke et al. 2008).

Generally, wet curing, slow drying and a diffusion phase enhance polycondensation of resins in the lumens. As a consequence, resin migration, cell wall penetration and bulking are reduced. Drying at low relative humidity favours cell wall penetration and the improvement of water-related properties such as dimensional stability. It should be considered that wood properties obtained from modification methods on laboratory scale are often different from those obtained for treating commercially sized timber in industrial processes, because drying conditions may be crucial for cell wall penetration of chemicals.

Acknowledgments The financial support of this work by the "Fachagentur Nachwachsende Rohstoffe (FNR)" is highly appreciated (Project No. 22004407). The authors would like to thank the work group "Chemistry and Processing Technique of Composite Materials", University of Göttingen for the possibility to perform densitometry.

Open Access This article is distributed under the terms of the Creative Commons Attribution License which permits any use, distribution, and reproduction in any medium, provided the original author(s) and the source are credited.

\section{References}

Ashaari Z, Barnes HM, Vasishth RC, Nicholas DD, Lyon DE (1990) Effect of aqueous polymer treatments on wood properties. Part 1: treatability and dimensional stability. International Research Group on Wood Protection, IRG/WP/3610, Stockholm

Becker G (1952) Untersuchungen über die Schutzwirkung von Pentachlorphenol gegen holzzerstörende Insekten. Holz Roh-Werkst 10(9):341-352

Brooks FW, Gayles MR, Watson RW (1973) The variability of preservative distribution in test blocks. International Research Group on Wood Protection, IRG/WP/220, Stockholm

Dieste A, Krause A, Bollmus S, Militz H (2009) Gluing ability of plywood produced with DMDHEUmodified veneers of Fagus sp., Betula sp., and Picea sp. Int J Adhes Adhes 29(2):206-209

Furuno T, Imamura Y, Kajita H (2004) The modification of wood by treatment with low molecular weight phenol-formaldehyde resin: a properties enhancement with neutralized phenolic-resin and resin penetration into wood cell walls. Wood Sci Technol 37:349-361

Galperin AS, Kuleshov GG, Tarashkevich VI, Shutov GM (1995) Manufacturing and properties of modified wood: a review of 25 years work. Holzforschung 49(1):45-50

Gindl W, Zargar-Yaghubi F, Wimmer R (2003) Impregnation of softwood cell walls with melamineformaldehyde resin. Bioresour Technol 87(3):325-330 
Gindl W, Hansmann C, Gierlinger N, Schwanninger M, Hinterstoisser B, Jeronimidis G (2004) Using a water-soluble melamine-formaldehyde resin to improve the hardness of Norway spruce wood. J Appl Polym Sci 93(4):1900-1907

Hill CAS (2006) Wood modification-chemical, thermal and other processes. Wiley-VCH Verlag, Weinheim. pp $149 \mathrm{ff}$

Hill CAS, Papadopoulos AN, Payne D (2004) Chemical modification employed as a means of probing the cell-wall micropore of pine sapwood. Wood Sci Technol 37(6):475-488

Jensen ES, Gatenholm P, Sellitti C (1992) An ATR-FTIR study on penetration of resins in wood. Die Angewandte Makromolekulare Chemie 200:77-92

Kamdem DP, Pizzi A, Jermannaud A (2002) Durability of heat-treated wood. Holz Roh-Werkst 60(1):1-6

Klüppel A, Mai C (2011) Untersuchungen zur Dauerhaftigkeit von modifiziertem Holz im Wasserbau, insbesondere gegenüber Teredo navalis. Fachagentur Nachwachsende Rohstoffe, final project report (project no. 22004407), p 90

Krause A (2006) Holzmodifizierung mit $N$-Methylolvernetzern. PhD thesis. Georg-August-Universität. Goettingen, Germany

Lande S (2008) Furfurylation of wood. PhD thesis. Norwegian University of Life Sciences. As, Norway

Lukowsky D, Peek RD (1998) Time dependent over-uptake of etherificated melamine resins. International Research Group on Wood Protection, IRG/WP 98-40109, Stockholm

Lukowsky D, Peek RD, Rapp AO (1998) Curing conditions for a low formaldehyde etherificated melamine resin. International Research Group on Wood Protection, IRG/WP 98-40108, Stockholm

Mantanis GI, Young RA, Rowell RM (1994) Swelling of wood. Part 1: swelling in water. Wood Sci Technol 28:119-134

Millett MA, Stamm AJ (1946) Treatment of wood with urea resin-forming systems. Part 1: dimension stability. Forest products laboratory report R1632. Oregon State University, Madison, Wisconsin

Millett MA, Stamm AJ (1954) Wood treatment with resin-forming systems. Part 3: a study of size and species limitations. Forest products laboratory report R1703, Oregon State University, Madison, Wisconsin

Millett MA, Seborg RM, Stamm AJ (1943) Influence of manufacturing variables on the impact resistance of resin-treated wood. Forest products laboratory report no. 1386. Oregon State University, Madison, Wisconsin

Nicholas DD, Williams AD (1987) Dimensional stabilization of wood with dimethylol compounds. International Research Group on Wood Protection, IRG/WP/3412, Stockholm

Ohmae K, Minato K, Norimoto M (2002) The analysis of dimensional changes due to chemical treatments and water soaking for Hinoki (Chamaecyparis obtusa) wood. Holzforschung 56:98-102

Olsson T, Megnis M, Varna J, Lindberg H (2001) Measurement of the uptake of linseed oil in pine by the use of an X-ray microdensitometry technique. J Wood Sci 47(4):275-281

Polge H (1978) 15 years of wood radiation densitometry. Wood Sci Technol 12(3):187-196

Poljansek I, Krajnc M (2005) Characterization of phenol-formaldehyde prepolymer resins by in line FT-IR spectroscopy. Acta Chim Slov 52(3):238-244

Rapp AO (1999) Physikalische und biologische Vergütung von Vollholz durch Imprägnierung mit wasserverdünnbaren Harzen. PhD thesis. Universität Hamburg. Hamburg

Rapp AO, Bestgen H, Adam W, Peek RD (1999) Electron energy loss spectroscopy (EELS) for quantification of cell-wall penetration of a melamine resin. Holzforschung 53(2):111-117

Schneider MH (1995) New cell-wall and cell lumen wood polymer composites. Wood Sci Technol 29(2):121-127

Seborg RM, Tarkow H, Stamm AJ (1953) Effect of heat upon the dimensional stabilization of wood. J For Prod Res Soc 3(3):59-67

Seborg RM, Tarkow H, Stamm AJ (1962). Modified woods. Forest products laboratory report no. 2192. Oregon State University, Madison, Wisconsin

Smith DN, Cockcroft R (1961) A method of obtaining uniform distribution of wood preservatives in toxicity test blocks. Nature 189(475):163-164

Stamm AJ (1934) Effect of inorganic salts upon the swelling and the shrinking of wood. J Am Chem Soc 56(5):1195-1204

Stamm AJ (1964) Factors affecting the bulking and dimensional stabilization of wood with polyethylene glycols. For Prod J 14(9):403-408

Stamm AJ, Seborg RM (1942). Resin-treated wood (Impreg). Forest products laboratory report no. 1380. Oregon State University, Madison, Wisconsin 
Stefke B, Windeisen E, Schwanninger M, Hinterstoisser B (2008) Determination of the weight percentage gain and of the acetyl group content of acetylated wood by means of different infrared spectroscopic methods. Anal Chem 80(4):1272-1279

Trinh HM, Militz H, Mai C (2012) Modification of beech veneers with N-methylol-melamine compounds for the production of plywood. Eur J Wood Prod 70:421-432

Wang S, Dai C (2004) Press control for optimized wood composite processing and properties. Part 2: properties and press control strategies. Fundamentals of composite processing: proceedings of a workshop. Forest products laboratory general technical report 149. Oregon State University, Madison, Wisconsin

Wepner F (2006) Entwicklung eines Modifizierungsverfahrens für Buchenfurniere (Fagus sylvatica L.) auf Basis von zyklischen N-Methylol-Verbindungen. $\mathrm{PhD}$ thesis. Georg-August-Universität. Goettingen 